\title{
PENGEMBANGAN BUKU AJAR PENDIDIKAN AGAMA ISLAM BERBASIS PENDIDIKAN KARAKTER DAN JIWA NASIONALIS
}

\author{
Yiyin Isgandi* dan Pandu Prasodjo \\ STKIP Al-Hikmah, Surabaya \\ *E-mail:yiyinisgandi@gmail.com
}

\begin{abstract}
The quality of Islamic Religion Education textbooks is still considered to be minimum. It has not been effective yet and been less valuable for pre-teacher students in teacher training and education university. This research aims to develop the PAI textbook based on characters education and nationalist soul in order to reduce radicalization towards religious understanding. Research method used in this research was research and development. The subjects and objects of this paper were PAI textbook and students of STKIP Al-Hikmah Surabaya. The data collected were analyzed both qualitatively and quantitatively. The results show that the book meets the needs of pre-teacher students. The students' responses towards the effectiveness, the quality, the standardization, and the value of developed PAI Textbook products is higher than the old book. The newest handbook average percentage is $85 \%$ compared to the old book, which shows $50 \%$ in percentage. This book is very valid and worth to use. The results of joint validation according to the expert reviewers and the students indicate that this book is suitable to use and it is categorized as "Very Good" which has 4.32 or $86 \%$ percentage in average score.
\end{abstract}

Keyword: Development, PAI (Islamic Religion Education) textbook, Character education, Nationalist soul

\begin{abstract}
ABSTRAK
Buku Ajar Pendidikan Agama Islam masih memiliki kualitas standar minimal, belum efektif, dan kurang bernilai tambah bagi calon pendidik di perguruan tinggi keguruan dan ilmu pendidikan. Penelitian ini bertujuan untuk mengembangkan Buku Ajar PAI berbasis pendidikan karakter dan jiwa nasionalis sebagai upaya deradikalisasi pemahaman agama. Metode penelitian menggunakan penelitian dan pengembangan. Subjek dan obyek penelitian adalab Buku Ajar PAI dan mahasiswa STKIP Al-Hikmah Surabaya. Data yang terkumpul dianalisis secara kualitatif dan kuantitatif. Hasil penelitian menunjukkan bahwa buku ini memenubi kebutuban calon pendidik. Nilai rata-rata respon mahasiswa terhadap efektifitas, kualitas, standarisasi, dan nilai tambah produk. buku PAI baru lebih tinggi daripada buku lama. Persentase skor rata-rata buku baru $85 \%$, lebih tinggi daripada buku lama 50\%. Buku ini juga sangat valid dan layak untuk digunakan. Hasil validasi menurut pakar abli dan mabasiswa menunjukkan buku ini layak. digunakan dengan predikat "Sangat Baik." dengan skor rata-rata 4,32 atau persentase 86\%.
\end{abstract}

Kata kunci: Pengembangan, Buku ajar PAI, Pendidikan karakter, Jiwa nasionalis. 


\section{PENDAHULUAN}

Lunturnya nilai-nilai jiwa nasionalis akibat tertangkapnya beberapa teroris yang mengatasnamakan Islam dan munculnya beberapa kelompok radikal yang sengaja melakukan radikalisasi pemahaman agama menjadi berita utama saat ini di Indonesia. Dekadensi moral, pergaulan bebas, dan pornografi juga semakin nyata di kalangan pelajar. Kondisi ini diberitakan secara massif di berbagai media elektronik, media massa dan sosial hingga membuat para akademisi dan pendidik khawatir akan masa depan bangsa. Para pendidik khususnya dosen bertanya-tanya, "Mengapa kejadian yang mencoreng dunia pendidikan itu terjadi di lingkungan pendidikan? Mengapa beberapa teroris dan pelaku kejahatan asusila yang tertangkap ada yang berstatus mahasiswa atau pelajar? Apakah dosen mata kuliah Pendidikan Agama Islam dan buku ajarnya tidak mampu mendidik mahasiswa untuk berjiwa nasionalis dan beragama Islam yang baik?”

Pendidikan Agama Islam sudah diajarkan sejak usia dini di sekolah, mulai tingkat dasar, tingkat menengah, dan tingkat atas. Bahkan sudah ditetapkan pengajaran agama di perguruan tinggi melalui Undang-Undang Nomor 22 tahun 1961 tentang Perguruan Tinggi. Meskipun saat itu penetapannya masih belum kuat karena pengaruh politik. Dalam BAB III Pasal 9 ayat 2 sub b dinyatakan: "Pada Perguruan Tinggi Negeri diberikan pendidikan agama sebagai mata pelajaran dengan pengertian bahwa mahasiswa berhak tidak ikut serta apabila menyatakan keberatan." Namun setelah kesadaran masyarakat tinggi akan bahaya paham komunisme dan atheisme, maka pembelajaran agama semakin terasa penting dan dibutuhkan. Tahun 1966 menjadi momentum menguatnya pendidikan agama melalui Ketetapan Majlis Permusyawaratan Rakyat Sementara (MPRS) XXVII/MPRS/ 1966. Yaitu pernyataan BAB I pasal 1 yang berbunyi: "Menetapkan Pendidikan Agama menjadi mata pelajaran di sekolah-sekolah mulai dari SD sampai Universitas-Universitas Negeri." Penetapan pendidikan agama ini terus berlanjut hingga sekarang dengan beragam kebijakan teknis mulai tingkat SD hingga perguruan tinggi baik negeri maupun swasta.

Berdasarkan amanat UndangUndang Nomor 12 Tahun 2012 tentang Pendidikan Tinggi Pasal 35 Ayat 3 dinyatakan bahwa mata kuliah Agama menjadi salah satu kurikulum pendidikan tinggi wajib selain mata kuliah Pancasila, Pendidikan Kewarganegaraan, dan Bahasa Indonesia untuk program sarjana dan diploma. Peraturan Menteri Riset Teknologi dan Pendidikan Tinggi No 44 tahun 2015 tentang Standar Nasional Pendidikan Tinggi juga telah memberi landasan hukum sangat kuat akan terlaksananya pembelajaran PAI.

Direktorat Jenderal Pembelajaran dan Kemahasiswaan Kementerian Riset, Teknologi, dan Pendidikan Tinggi juga telah menyusun Buku Bahan Ajar Mata Kuliah Wajib PAI terbit tahun 2016 untuk memperkuat wahana pendidikan karakter bangsa Indonesia dalam rangka menghadapi era globalisasi dan 
Masyarakat Ekonomi ASEAN (MEA). Buku ini juga diharapkan mampu mengantarkan mahasiswa bersikap adaptif, kompetitif, dan menjadi lulusan yang cinta tanah air, siap bela negara, serta mampu meningkatkan jati diri bangsanya. Namun peneliti melihat bahwa Buku Bahan Ajar PAI tersebut masih memiliki standar kemampuan lulusan minimal untuk semua mahasiswa di perguruan tinggi. Buku ini diyakini kurang efektif dan kurang bernilai tambah bagi mahasiswa calon pendidik. Mereka membutuhkan pendidikan agama Islam yang terintegrasi dengan aspek-aspek keguruan dan kebangsaan sehingga buku tersebut perlu pengembangan. Khususnya pengembangan untuk mendidik karakter dan jiwa nasionalis mahasiswa calon pendidik.

Realitas lain di beberapa perguruan tinggi bentuk Buku Ajar PAI bervariasi. Ada yang bersifat dogmatis berdasar paham tertentu, dominan aspek kognitif daripada aspek afektif dan aspek psikomotor, kurang merangsang mahasiswa untuk menambah wawasan keislaman dan kebangsaan, serta minim implementasi nilai-nilai pendidikan karakter dan jiwa nasionalis. Terbukti beberapa kampus di Indonesia menjadi pusat gerakan yang mengajarkan pahampaham radikal dalam beragama Islam. Peneliti LIPI Anas Saidi (2017) menyatakan hasil penelitian "Mahasiswa Islam dan Masa Depan Demokrasi di Indonesia" tahun 2015 bahwa radikalisme tumbuh subur di kampus Perguruan Tinggi Umum. Sebanyak 86\% mahasiswa di lima PTU besar di Jawa menolak ideologi Pancasila dan bersikeras untuk menegakkan Syariat Islam. Menurut survei The Pew Research
Center pada 2015 disebutkan 4\% orang Indonesia mendukung Islam State (Suwendi, 2017: p 15).

Guna memenuhi kebutuhan akan pemahaman yang benar tentang Islam dan hubungannya dengan pendidikan karakter dan wawasan kebangsaan, maka dibutuhkan penelitian pengembangan Buku Ajar PAI berbasis pendidikan karakter dan jiwa nasionalis sebagai upaya deradikalisasi pemahaman. Artikel ini menjelaskan hasil pengembangan buku ajar PAI yang baru bagi mahasiswa calon pendidik dan hasil uji kelayakan untuk dapat digunakan dalam pembelajaran.

Pengembangan yang dimaksud adalah proses pemilihan, adaptasi, dan pembuatan buku ajar berdasarkan kerangka acuan tertentu. Mendesain buku yang berusaha menimbulkan minat baca, belajar, dan rasa ingin tahu mahasiswa, menjelaskan tujuan instruksional, dapat dipergunakan oleh dosen dan mahasiswa dalam proses perkuliahan, yang disusun berdasar pola belajar fleksibel, sistematis, dan terstruktur. Pengembangan buku juga berdasarkan pada kebutuhan mahasiswa dan kompetensi akhir yang ingin dicapai, fokus pada pemberian kesempatan bagi mahasiswa untuk berlatih, berdiskusi, dan internalisasi nilai positif dengan gaya penulisan yang komunikatif, serta ada umpan balik. Materi disusun berdasarkan pada Standar Kompetensi Lulusan, substansi kajian, deskripsi dan silabus yang sesuai dengan SK Dirjen Dikti Depdiknas Nomor 43 /DIKTI/Kep/ 2006 tentang Rambu-Rambu Pelaksanaan Kelompok Matakuliah Pengembangan Kepribadian di Perguruan Tinggi tertanggal 2 Juni 2006. 
Buku ajar PAI dikembangkan berbasis pendidikan karakter karena karakter adalah sesuatu yang amat tinggi nilainya sehingga jika ia tidak melekat pada diri seseorang, maka tiadalah harga diri orang tersebut (Budimansayah dan Komalasari, 2011: v). Undang-undang Nomor 20 tahun 2003 tentang Sistem Pendidikan Nasional RI pasal 339 menghendaki bahwa pendidikan di Indonesia harus mengarahkan warga penduduknya kepada kehidupan yang beragama, kehidupan yang menerapkan nilai-nilai agama dalam tataran real kehidupan sehari-hari. Sebagai realisasi dari peraturan tersebut maka pembentukan karakter dan pembiasaan akhlak mulia merupakan cara yang dapat dipilih untuk menjadikan pendidikan lebih bersifat menyeluruh dengan saling keterkaitan antar elemen (Sumantri, 2007).

Jiwa nasionalis yang dimaksud di sini adalah nilai, sifat, atau prilaku orang yang mencintai bangsa dan tanah airnya, atau yang memperjuangkan kepentingan bangsa (Tim Pusat Bahasa, 2016). Jiwa nasionalis membentuk jiwa kesadaran mencintai bangsa dan tanah air karena Allah yang memerintahkan, sehingga loyalitas tertinggi ditujukan kepada kebenaran. Contoh sederhana jika negara memerintah untuk membunuh rakyatnya sendiri seperti yang terjadi di negara Suriah, maka ia tidak akan melakukannya demi kemanusiaan dan rasa cintanya kepada bangsa dan rakyat sendiri. Berdasarkan definisi jiwa nasionalis di atas, maka seseorang dapat dikatakan mempunyai jiwa nasionalis jika pada dirinya terdapat nilai-nilai sebagai berikut:

1. Mencintai bangsa dan tanah airnya.
2. Mencintai negara dan simbol negaranya

3. Tidak berbuat hal-hal yang dapat merugikan bangsa dan negaranya

4. Selalu berbuat baik untuk kepentingan bangsa dan negaranya.

5. Harus berjuang rela menderita untuk kepentingan bangsa dan negaranya.

\section{METODE PENELITIAN}

Penelitian ini menggunakan metode penelitian dan pengembangan.Menurut Borg dan Gall (1998) sebagaimana dikutip oleh Sugiyono (2016:28) bahwa penelitian dan pengembangan merupakan proses / metode yang digunakan untuk memvalidasi dan mengembangkan produk. Hasil penelitian digunakan untuk merancang produk baru dan prosedur, yang selanjutnya diuji di lapangan secara sistematis, dievaluasi, dan disempurnakan sampai memenuhi kriteria yang spesifik yaitu efektifitas, kualitas, dan memenuhi standar (Borg dan Gall, 2003). Plomp dan Nieveen (2007) menambahkan kriteria "dapat menunjukkan nilai tambah" selain ketiga kriteria di atas.

Borg dan Gall (2003) membuat sepuluh langkah. Sukmadinata dan kawan-kawan mengembangkannya hanya menjadi tiga tahap saja, yaitu: 1) Studi Pendahuluan, 2) Pengembangan Model, dan 3) Uji Model. Penulis melakukan studi pendahuluan untuk studi kepustakaan, survei lapangan, dan penyusunan desain produk awal Buku Ajar PAI. Dalam tahap pengembangan penulis melakukan langkah uji pakar, uji coba terbatas di kelas program studi Pendidikan Bahasa 
Inggris, dan uji coba lebih luas di semua prodi di STKIP Al Hikmah Surabaya. Di tahap akhir uji produk utama untuk pengujian efektifitas, kualitas, standarisasi, dan nilai tambah produk baru, lalu didesiminasikan. Secara bertahap bisa digambarkan di gambar 2.1. berikut ini:

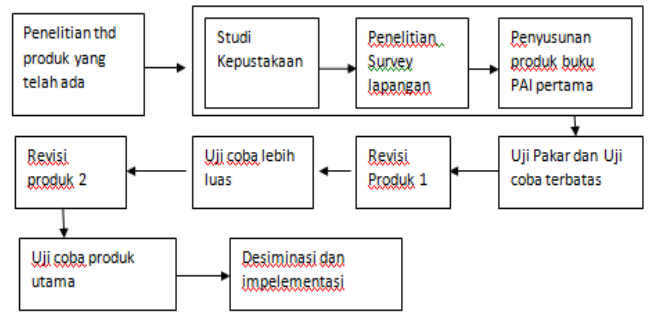

ngan Buku Ajar PAI

Subjek penelitian pengembangan ini adalah Buku Ajar PAI berbasis pendidikan karakter dan jiwa nasionalis, serta 55 mahasiswa dan 10 dosen/pengasuh di STKIP Al-Hikmah Surabaya. Pengumpulan data menggunakan dokumentasi melalui observasi, wawancara tidak terstruktur, dan angket. Instrumen angket menggunakan pengukuran skala Likert. Yaitu sebuah skala pengukuran yang digunakan untuk mengukur sikap, pendapat, dan persepsi seseorang atau kelompok orang tentang sebuah fenomena sosial (Sugiono, 2016: 93). Peneliti menetapkan empat indikator variabel; efektifitas, kualitas, standarisasi, dan nilai tambah. Indikator efektifitas dikembangkan menjadi dua pertanyaan, indikator kualitas dikembangkan menjadi dua pertanyaan, indikator standarisasi dikembangkan menjadi tiga pertanyaan, serta indikator nilai tambah dikembangkan menjadi tiga pertanyaan. Jawaban setiap item instrumen mempunyai lima gradasi dari sangat positif sampai sangat negatif, serta dilakukan penskoran untuk keperluan analisis kuantitatif. Yaitu Sangat Baik (5), Baik (4), Cukup (3), Kurang (2), dan Sangat Kurang (1).

Pada tahap pengembangan desain produk awal, dokumen yang digunakan adalah sumber primer berupa Buku Ajar PAI yang diterbitkan Ristekdikti tahun 2016, Silabus yang berisikan SK dan KD sesuai SN DIKTI, Rencana Pembelajaran Semester (RPS), Rencana Pelaksanaan Pembelajaran (RPP), dan visi misi pembelajaran PAI di Perguruan Tinggi. Peneliti mendesain produk buku PAI berbasis pada pendidikan karakter dan jiwa nasionalis. Setelah diskusi dengan pakar ahli dan pengalaman empiris, peneliti hanya menggunakan tiga dari empat aspek kelayakan buku ajar yang ditetapkan Badan Standar Nasional Pendidikan (BSNP); (1) kelayakan bahasa, (2) kelayakan konstruk penyajian, dan (3) kelayakan konten/isi, sehingga diperoleh desain model Buku Ajar PAI yang pertama.

Pada tahap uji pakar dilakukan validasi instrumen dan review produk oleh tiga pakar ahli bidangkebahasaan dan Pendidikan Agama Islam. Instrumen validasi produk menggunakan skala pengukuran Rating-Scale. Yaitu pengumpulan data mentah yang diperoleh berupa angka kemudian ditafsirkan dalam pengertian kualitatif (Sugiono, 2016: 97). Validasi produk oleh mahasiswa juga menggunakan instrumen yang sama dengan lima gradasi mulai dari positif hingga negatif. Selain penilaian, mereka juga memberikan masukan atau saran terkait dengan tiga aspek kelayakan di atas.

Dari telaah buku oleh uji pakar dan uji coba terbatas maka didapatkan 
saran dan masukan yang akan disajikan dalam model buku ajar PAI kedua. Hasil revisi produk kedua diuji cobakan lebih luas ke mahasiswa semua prodi dan dilakukan penyebaran angket validasi dan masukan untuk revisi akhir. Hasil revisi akhir dimasukkan menjadi produk utama dan diuji cobakan, lalu didesiminasikan, dan diimplementasikan dalam pembelajaran PAI di perguruan tinggi keguruan dan ilmu pendidikan.

Teknik analisis data yang digunakan dalam penelitian pengembangan buku ajar PAI ini adalah gabungan analisis data kualitatif dan kuantitatif. Analisis data kualitatif dilakukan untuk menganalisa data dari lembar observasi, wawancara tidak terstruktur, dan dokumentasi lain. Analisis data kuantitatif dilakukan dengan menggunakan analisis frekuensi. Analisis data dengan menjumlahkan skor tiap butir pernyataan, menghitung skor total rata-rata dari setiap aspek, menghitung persentase dan mengubahnya menjadi kategori. Adapun analisis validasi produk dilakukan dengan mengubah data kuantitatif pada Rating Scale menjadi data kualitatif, yaitu menjumlahkan skor tiap butir pernyataan dari tiap aspek penilaian, menghitung skor total rata-rata dari tiap aspek, mengubah skor rata-rata menjadi persentase, dan mengubah menjadi kategori kelayakan berdasarkan pedoman konversi skala lima menurut Sukardjo dan Lis Permana Sari (2009), yang kemudian disesuaikan oleh peneliti. Rumus katagori kelayakan yang digunakan adalah sebagai berikut:

Tabel 2.1. Rumus Katagori Kelayakan (Konversi Data Kuantitatif Menjadi Data Kualitatif)

\begin{tabular}{|c|c|c|c|c|}
\hline $\begin{array}{c}\mathbf{N} \\
\mathbf{o}\end{array}$ & Rumus & $\begin{array}{c}\text { Rentan } \\
\text { g Skor }\end{array}$ & $\begin{array}{c}\text { Prosen } \\
\text {-tase }\end{array}$ & Katagori \\
\hline 1 & $\begin{array}{l}\mathrm{Mi}+1,80 \mathrm{~S} \\
\mathrm{bi}<\mathrm{X}\end{array}$ & $\begin{array}{l}4,20< \\
X\end{array}$ & $\begin{array}{l}84 \%< \\
X\end{array}$ & $\begin{array}{l}\text { Layak dengan } \\
\text { predikat } \\
\text { "Sangat Baik" }\end{array}$ \\
\hline 2 & $\begin{array}{l}\mathrm{Mi}+0,60 \mathrm{~S} \\
\mathrm{bi}<\mathrm{X} \leq \\
\mathrm{Mi}+1,80 \mathrm{~S} \\
\mathrm{bi}\end{array}$ & $\begin{array}{l}3,40< \\
X \leq \\
4,20\end{array}$ & $\begin{array}{l}68 \%< \\
X \leq \\
84 \%\end{array}$ & $\begin{array}{l}\text { Layak dengan } \\
\text { predikat } \\
\text { "Baik" }\end{array}$ \\
\hline 3 & $\begin{array}{l}\text { Mi- } \\
0,60 \text { Sbi }< \\
\mathrm{X} \leq \\
\mathrm{Mi}+0,06 \mathrm{~S} \\
\text { bi }\end{array}$ & $\begin{array}{l}2,60< \\
x \leq \\
3,40\end{array}$ & $\begin{array}{l}52 \%< \\
X \leq \\
68 \%\end{array}$ & $\begin{array}{l}\text { Layak dengan } \\
\text { predikat } \\
\text { "Cukup Baik" }\end{array}$ \\
\hline 4 & $\begin{array}{l}\text { Mi- } \\
1,80 \text { Sbi }< \\
\mathrm{X} \leq \mathrm{Mi}- \\
0,06 \mathrm{Sbi}\end{array}$ & $\begin{array}{l}1,80< \\
X \leq \\
2,60\end{array}$ & $\begin{array}{l}36 \%< \\
X \leq \\
52 \%\end{array}$ & $\begin{array}{l}\text { Tidak Layak } \\
\text { dengan } \\
\text { predikat } \\
\text { "Kurang } \\
\text { Baik" }\end{array}$ \\
\hline 5 & $\begin{array}{l}\mathrm{X} \leq \mathrm{Mi}- \\
1,80 \mathrm{Sbi}\end{array}$ & $\begin{array}{l}X \leq \\
1,80\end{array}$ & $\begin{array}{l}X \leq \\
36 \%\end{array}$ & $\begin{array}{l}\text { Tidak Layak } \\
\text { dengan } \\
\text { predikat } \\
\text { "Sangat } \\
\text { Kurang Baik" }\end{array}$ \\
\hline
\end{tabular}

Keterangan:

$\mathbf{X}=$ Skor yang dicapai

Mi $=$ Mean ideal $=1 / 2$ (skor maksimal ideal + skor minimal ideal)

Sbi $=$ Simpangan buku ideal $=1 / 6$ (skor maksimal ideal skor minimal ideal)

Tabel 2.1. di atas menunjukkan bahwa buku ajar PAI dikatakan valid dan layak digunakan, jika memenuhi katagori penilaian minimal "Cukup Baik". Jadi, jika hasil penilaian akhir dari dosen pakar ahli, dosen/pengasuh, dan mahasiswa minimal "Cukup Baik", maka produk pengembangan buku ajar PAI berbasis pendidikan karakter dan jiwa nasionalis untuk mahasiswa keguruan dan ilmu pendidikan ini layak digunakan. Tabel tersebut juga menjelaskan bahwa buku ajar PAI yang valid dan layak digunakan dalam pembelajaran PAI harus memperoleh skor rata-rata di atas 2,60 atau prosentase skor rata-rata di atas 52\%. Jika memperoleh skor rata-rata di bawah skor tersebut, maka buku tersebut tidak layak untuk digunakan. 


\section{HASIL PENELITIAN DAN PEMBAHASAN}

Sebelum mengembangkan buku ajar PAI telah dilakukan studi pendahuluan berupa pengumpulan data melalui observasi dan wawancara tidak terstruktur kepada dosen dan mahasiswa tentang kebutuhan dan harapan calon pendidik. Berdasar hasil observasi dan wawancara, diketahui bahwa mereka membutuhkan pendidikan karakter keguruan dan jiwa nasionalis terintegrasi dalam pembelajaran PAI. Mereka perlu pendalaman dan internalisasi adab belajar dan mengajar dalam Islam, pendidikan keluarga, serta wawasan kebangsaan sebagai upaya deradikalisasi pemahaman agama.

Penyebaran angket kepada 10 dosen dan 55 mahasiswa tentang respon mereka terhadap efektifitas, kualitas, standarisasi, dan nilai tambah buku ajar PAI terbitan Belmawa Ristekdikti tahun 2016 bagi calon pendidik juga dilakukan. Hasilnya diperoleh skor rata-rata sebagai berikut; efektifitas memperoleh 1,96 atau persentase $39 \%$ dengan katagori "Kurang Baik", kualitas memperoleh 2,4 atau $48 \%$ dengan katagori "Kurang Baik", standarisasi memperoleh 3,2 atau 64\% dengan katagori "Cukup Baik", dan nilai tambah memperoleh 2,0 atau 41\% dengan katagori "Kurang Baik". Dapat disimpulkan bahwa buku PAI tersebut telah memenuhi standar nasional Dikti untuk mahasiswa umum di perguruan tinggi, tapi hanya memiliki standar minimal. Buku tersebut ternyata juga tidak efektif, kurang berkualitas, dan kurang bernilai tambah bagi mahasiswa calon pendidik. Karena itulah buku tersebut perlu dikembangkan sesuai kebutuhan dan harapan calon pendidik.

Dalam pengembangan dan pembuatan desain model awal buku ajar PAI dilakukan penentuan sepuluh tujuan pembelajaran sesuai Standar Kompetensi dan Kompetensi Dasar di Rencana Pembelajaran Semester, pemilihan bahan ajar dan referensi, serta penyusunan kerangka buku ajar. Sepuluh tujuan pembelajaran tesebut dijadikan sepuluh Kompetensi Dasar, yang secara otomatis menjadi sepuluh judul bab sebagai berikut:

Tabel 3.1. Daftar Judul Bab dalam Produk Buku Ajar PAI Baru untuk Calon Pendidik

\begin{tabular}{|c|l|}
\hline Bab & \multicolumn{1}{|c|}{ Kompetensi Dasar } \\
\hline I & $\begin{array}{l}\text { Mengkaji Model Pembelajaran PAI } \\
\text { di Perguruan Tinggi dan Pola } \\
\text { Pemikiran Umat Muslim }\end{array}$ \\
\hline II & $\begin{array}{l}\text { Menjadikan Alquran dan Sunnah } \\
\text { sebagai Sumber Utama Agama } \\
\text { Islam }\end{array}$ \\
\hline III & $\begin{array}{l}\text { Mengkaji Ijtihad sebagai Sumber } \\
\text { Sekunder Agama Islam }\end{array}$ \\
\hline IX & $\begin{array}{l}\text { Mengkaji Aqidah dan Tauhid yang } \\
\text { Benar }\end{array}$ \\
\hline V & Mengkaji Ibadah yang Benar \\
\hline VI & $\begin{array}{l}\text { Mengkaji Akhlak Guru dan Adab } \\
\text { Belajar Mengajar }\end{array}$ \\
\hline VII & $\begin{array}{l}\text { Mengkaji Pendidikan Keluarga } \\
\text { dalam Islam }\end{array}$ \\
\hline VIII & $\begin{array}{l}\text { Mengkaji Pengaruh Sosial Budaya } \\
\text { dalam Beragama dan Dakwah }\end{array}$ \\
\hline $\mathbf{X}$ & $\begin{array}{l}\text { Menginternalisasi nilai-Nilai HAM } \\
\text { dan Demokrasi Positif di } \\
\text { Indonesia }\end{array}$ \\
\hline yang Toleran di Indonesia \\
\hline
\end{tabular}

Berdasarkan tabel 3.1. pembelajaran PAI itu seperti menanam Pohon Tauhid. Mahasiswa terlebih dahulu 
diajak untuk memahami cara menanam pohon, memelihara, dan menjaganya agar dapat menghasilkan buah akhlak mulia melalui kajian model pembelajaran dan pola pikir umat. Agar akar pohon itu kuat menghujam ke bumi mahasiswa mengkaji sumber utama agama Islam, yaitu Alquran dan sunnah, lalu ijtihad sebagai sumber sekunder yang dinamis. Memiliki aqidah kuat dan menjalankan ibadah yang benar sebagai batang kokoh yang mampu menembus langit guna menopang dahan, ranting, daun, dan buah akhlak mulia. Sebagai calon pendidik, keteladanan akhlak mulia dan kepribadian baik merupakan hal terpenting. Inilah buah Pohon Tauhid. Calon pendidik wajib berakhlak mulia, beradab, memiliki sopan santun baik saat belajar, mengajar, dan bermasyarakat. Termasuk buah adalah memahami konsep pendidikan keluarga dalam Islam, berdakwah dengan memahami keadaan sosial budaya dan cara-cara terbaik, mengerti Hak Asasi Manusia dan demokrasi yang berlaku di Indonesia, serta mampu membawa misi Islam rabmatan lilalamin, yaitu mewujudkan masyarakat madani yang toleran anti radikalisme, ekstrimesme, dan terorisme di tanah air tercinta Indonesia.

Setelah tersusun menjadi desain produk buku ajar model awal, maka buku tersebut direview dan dinilai aspek kelayakan bahasa, kelayakan konstruk penyajian, dan kelayakan konten. Pertama dari pakar ahli Adi Dwi Achmad P, M.Pd dari STKIP Al Hikmah Surabaya diperoleh hasil penilaian dari tiga aspek berikut ini:
Tabel 3.2. Data Skor Rata-Rata Hasil Validasi Dosen Ahli Pertama

\begin{tabular}{|c|l|c|c|}
\hline No & Aspek Penilaian & Skor & $\begin{array}{c}\text { Persen- } \\
\text { tase }\end{array}$ \\
\hline 1 & Kelayakan Bahasa & 3,5 & $70 \%$ \\
\hline 2 & $\begin{array}{l}\text { Kelayakan } \\
\text { Konstruk } \\
\text { Penyajian }\end{array}$ & 4 & $80 \%$ \\
\hline 3 & $\begin{array}{l}\text { Kelayakan } \\
\text { Konten/Isi }\end{array}$ & 4,2 & $84 \%$ \\
\hline Jumlah & $\mathbf{3 , 9}$ & $78 \%$ \\
\hline Skor Rata-Rata & Baik & Baik \\
\hline Katagori & & \\
\hline
\end{tabular}

Berdasarkan tabel 3.2. skor ratarata yang diperoleh dari penilaian pakar ahli tersebut pada semua aspek adalah 3,9 atau persentase $78 \%$ dalam katagori "Baik". Pakar ahli juga memberikan beberapa kritik dan saran, yaitu (1) memberikan gambar dan ilustrasi agar terlihat lebih menarik, (2) menggunakan kata baku dalam Bahasa Indonesia, (3) konsisten dalam penggunaan istilah, dan (4) memperbaiki konstruk dan sistematika penyajian bab dan subbab. Hasil revisi ini menjadi bahan perbaikan produk awal. Produk hasil perbaikan lalu direview dan divalidasi ulang oleh tiga pakar ahli, yaitu Ady Dwi Achmad P, M.Pd. untuk yang kedua kalinya, Dr. Muhammad Turhan Yani, MA seorang dosen PAI dari Universitas Negeri Surabaya, dan Dr. Hammis Syafaq seorang dosen Ilmu Agama Islam dari Universitas Islam Negeri Sunan Ampel Surabaya. Akumulasi hasil penilaian dari tiga pakar ahli kebahasaan dan Pendidikan Agama Islam sebagai berikut: Tabel 3.3. Data Akumulasi Hasil Validasi Tiga Pakar Ahli

\begin{tabular}{|c|l|c|c|c|c|c|}
\hline \multirow{2}{*}{$\begin{array}{c}\text { N } \\
\mathbf{o}\end{array}$} & \multicolumn{1}{|c|}{$\begin{array}{c}\text { Aspek } \\
\text { Penilaian }\end{array}$} & \multicolumn{3}{|c|}{ Reviewer } & \multirow{2}{*}{$\begin{array}{c}\text { Skor } \\
\text { Rerata }\end{array}$} & $\begin{array}{c}\text { Pers } \\
\text { enta } \\
\text { se }\end{array}$ \\
\hline 1 & $\begin{array}{l}\text { Kelayakan } \\
\text { Bahasa }\end{array}$ & 4,7 & 4,5 & 4,3 & 4,5 & $90 \%$ \\
\hline 2 & Kelayakan & 4,6 & 4,5 & 4,4 & 4,5 & $90 \%$ \\
\hline
\end{tabular}




\begin{tabular}{|c|c|c|c|c|c|c|}
\hline & $\begin{array}{l}\text { Konstruk } \\
\text { Penyajian }\end{array}$ & & & & & \\
\hline 3 & $\begin{array}{l}\text { Kelayakan } \\
\text { Konten/Isi }\end{array}$ & 4,9 & 4,7 & 4,8 & 4,8 & $96 \%$ \\
\hline & nlah & $\begin{array}{c}14, \\
2\end{array}$ & $\begin{array}{c}13, \\
7\end{array}$ & $\begin{array}{c}13, \\
5\end{array}$ & 13,8 & $92 \%$ \\
\hline & or Rata-Rata & $\begin{array}{c}4,7 \\
3\end{array}$ & $\begin{array}{c}4,5 \\
5\end{array}$ & 4,5 & 4,6 & $92 \%$ \\
\hline & tagori & $\begin{array}{l}\text { Sa } \\
\text { ng } \\
\text { at } \\
\text { Ba } \\
\text { ik }\end{array}$ & $\begin{array}{l}\text { Sa } \\
\text { ng } \\
\text { at } \\
\text { Ba } \\
\text { ik }\end{array}$ & $\begin{array}{l}\text { Sa } \\
\text { ng } \\
\text { at } \\
\text { Ba } \\
\text { ik }\end{array}$ & $\begin{array}{c}\text { Sangat } \\
\text { Baik }\end{array}$ & $\begin{array}{l}\text { Sang } \\
\text { at } \\
\text { Baik }\end{array}$ \\
\hline
\end{tabular}

Tabel 3.3. menunjukkan adanya peningkatan setelah perbaikan dengan skor rata-rata 4,6 atau persentase 92\% dalam katagori "Sangat Baik". Dalam validasi uji pakar ini ada beberapa masukan dari ketiga pakar ahli, yaitu (1) indikator dari masing-masing tujuan pembelajaran perlu dicantumkan di awal bab, (2) konsistensi penulisan istilah bahasa Arab harus sesuai dengan pedoman transiliterasi Arab-Latin, (3) daftar pustaka dicantumkan di akhir setiap bab, dan (4) konstruksi penyajian lebih dirunut. Setelah sedikit revisi, produk buku ini diujicobakan di kelas terbatas pada 15 mahasiswa prodi pendidikan bahasa Inggris. Pengujian terbatas dilakukan dengan metode eksperimen, yaitu membandingkan efektifitas produk buku PAI lama dengan yang baru dalam pembelajaran. Produk baru diukur berdasarkan efektifitas, kualitas, standarisasi, dan nilai tambah. Jadi indikator keberhasilan yang dapat diukur adalah empat indikator tersebut dengan membandingkan penilaian produk lama dan penilaian produk baru (before-after). Seperti gambar 3.1 berikut ini:

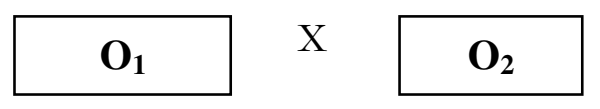

Gambar 3.1. Desain eksperimen (beforeafter). $\mathrm{O}_{1}$ adalah nilai produk lama, $\mathrm{O}_{2}$ adalah nilai produk baru, dan $\mathrm{X}$ adalah pengembangan produk baru (modifikasi dari Sugiono, 2016: 303)

Setelah penilain produk lama dan baru, dilakukan perbandingan antara keduanya seperti hasil perbandingan pada tabel 3.4. Tabel 3.4 Perbandingan Produk Buku

Ajar PAI Lama dan Baru

\begin{tabular}{|c|c|l|c|c|}
\hline $\begin{array}{c}\text { Skor } \\
\text { Rata } \\
-\end{array}$ & $\begin{array}{c}\text { Persentas } \\
\text { e } \\
\text { Rata } \\
\text { PAI } \\
\text { Lam } \\
\text { a }\end{array}$ & $\begin{array}{c}\text { Lama } \\
\text { Penilaian } \\
\text { Produk } \\
\text { PAI }\end{array}$ & $\begin{array}{c}\text { Skor } \\
\text { Rata- } \\
\text { Rata } \\
\text { PAI } \\
\text { Baru }\end{array}$ & $\begin{array}{c}\text { Persen } \\
\text { tase } \\
\text { PAI } \\
\text { Baru }\end{array}$ \\
\hline 2 & $40 \%$ & $\begin{array}{l}\text { Efekti- } \\
\text { fitas }\end{array}$ & 4,25 & $85 \%$ \\
\hline 2,6 & $52 \%$ & Kualitas & 4,39 & $88 \%$ \\
\hline 3,2 & $64 \%$ & $\begin{array}{l}\text { Standa- } \\
\text { risasi }\end{array}$ & 4,1 & $82 \%$ \\
\hline 2,1 & $42 \%$ & $\begin{array}{l}\text { Nilai } \\
\text { Tambah }\end{array}$ & 4,2 & $84 \%$ \\
\hline $\mathbf{2 , 5}$ & $\mathbf{5 0 \%}$ & $\begin{array}{l}\text { Rata- } \\
\text { Rata }\end{array}$ & $\mathbf{4 , 2 5}$ & $\mathbf{8 5 \%}$ \\
\hline
\end{tabular}

Pada tabel 3.4 terlihat bahwa skor rata-rata produk buku ajar PAI baru lebih tinggi dari produk lama. Rata-rata penilaian PAI lama $=2,5$ atau $50 \%$ dan PAI baru $=4,25$ atau 85\%. Dengan perincian efektifitas PAI lama $=2$ atau $40 \%$ berbanding efektifitas PAI baru 4,25 atau 85\%. Kualitas PAI lama $=2,6$ atau $52 \%$ berbanding kualitas PAI baru 4,39 atau $88 \%$. Standarisasi PAI lama $=$ 3,2 atau $64 \%$ berbanding standarisasi PAI baru 4,1 atau $82 \%$. Nilai tambah PAI lama $=2,1$ atau $42 \%$ berbanding nilai tambah PAI baru 4,2 atau 84\%. Berdasarkan data tersebut jelas terlihat bahwa desain produk awal buku ajar PAI baru dapat meningkatkan efektifitas, kualitas, standarisasi, dan nilai tambah bagi mahasiswa calon pendidik. 
Di saat yang sama peneliti juga mengambil data validasi kelayakan produk baru dengan hasil sebagaimana tabel 3.5 berikut ini:

Tabel 3.5. Data skor rata-rata hasil validasi uji coba terbatas pada keseluruhan aspek

\begin{tabular}{|c|l|c|c|c|}
\hline $\begin{array}{c}\mathrm{N} \\
\mathrm{O}\end{array}$ & $\begin{array}{c}\text { Aspek } \\
\text { Penilaian }\end{array}$ & $\begin{array}{c}\text { Skor } \\
\text { Rera-ta }\end{array}$ & $\begin{array}{c}\text { Persen } \\
\text {-tase }\end{array}$ & Katagori \\
\hline 1 & $\begin{array}{l}\text { Kelayakan } \\
\text { Bahasa }\end{array}$ & 4 & $80 \%$ & Baik \\
\hline 2 & $\begin{array}{l}\text { Kelayakan } \\
\text { Konstruk } \\
\text { Penyajian }\end{array}$ & 4,1 & $82 \%$ & Baik \\
\hline 3 & $\begin{array}{l}\text { Kelayakan } \\
\text { Konten/ } \\
\text { Isi }\end{array}$ & 4,2 & $84 \%$ & Baik \\
\hline \multicolumn{2}{|l|}{ Jumlah } & 12,3 & $82 \%$ & Baik \\
\hline \multicolumn{2}{|l|}{ Skor Rata-Rata } & $\mathbf{4 , 1}$ & $\mathbf{8 2} \%$ & Baik \\
\hline
\end{tabular}

Berdasarkan pada tabel 3.5. skor yang didapat dari validasi produk saat uji coba terbatas pada mahasiswa adalah 4,1 atau $82 \%$ dengan katagori "Baik". Mahasiswa memberi kesan bahwa buku ajar PAI baru ini mudah dipahami, merangsang mahasiswa untuk berpikir kritis dan argumentatif, pendidikan karakter dan jiwa nasionalis sangat kuat, dan sangat efektif bagi mahasiswa calon pendidik sesuai kebutuhan dan harapan di lapangan. Mereka juga memberi saran; (1) memperbanyak masalah ri'il yang dihadapi oleh guru di sekolah dan masyarakat beserta solusi alternatifnya dalam Islam, (2) menambah gambar dan ilustrasi yang lebih menarik, dan (3) mempersedikit istilah asing yang kurang familiar di kalangan mahasiswa. Buku ajar ini diperbaiki lagi berdasarkan hasil validasi tiga pakar ahli dan hasil uji coba terbatas menghasilkan produk buku ajar model kedua. Kemudian produk ini diuji lagi pada objek mahasiswa yang lebih luas di semua program studi yang ada di STKIP Al Hikmah yang berjumlah 55 mahasiswa. Dari uji coba lebih luas diperoleh hasil sebagai berikut;

Tabel 3.6. Data skor rata-rata hasil validasi mahasiswa objek uji coba lebih luas

\begin{tabular}{|c|l|c|c|c|}
\hline No & \multicolumn{1}{|c|}{$\begin{array}{c}\text { Aspek } \\
\text { Penilaian }\end{array}$} & $\begin{array}{c}\text { Skor } \\
\text { Rerata }\end{array}$ & $\begin{array}{c}\text { Persen } \\
\text {-tase }\end{array}$ & Katagori \\
\hline 1 & $\begin{array}{l}\text { Kelayakan } \\
\text { Bahasa }\end{array}$ & 4,3 & $86 \%$ & $\begin{array}{c}\text { Sangat } \\
\text { Baik }\end{array}$ \\
\hline 2 & $\begin{array}{l}\text { Kelayakan } \\
\text { Konstruk } \\
\text { Penyajian }\end{array}$ & 4,2 & $84 \%$ & Baik \\
\hline 3 & $\begin{array}{l}\text { Kelayakan } \\
\text { Konten/Isi }\end{array}$ & 4,3 & $86 \%$ & $\begin{array}{c}\text { Sangat } \\
\text { Baik }\end{array}$ \\
\hline Jumlah & 12,8 & $85 \%$ & $\begin{array}{c}\text { Sangat } \\
\text { Baik }\end{array}$ \\
\hline \multicolumn{2}{|l|}{ Skor Rata-Rata } & $\mathbf{4 , 2 6}$ & $\mathbf{8 5 \%}$ & $\begin{array}{c}\text { Sangat } \\
\text { Baik }\end{array}$ \\
\hline
\end{tabular}

Tabel 3.6. memperlihatkan bahwa hasil validasi uji coba lebih luas adalah 4,26 atau persentase $85 \%$ dengan katagori "Sangat Baik". Beberapa masukan dari mahasiswa di antaranya 1) menambah materi zakat, wakaf, dan pembagian harta waris, dan 2) implementasi cinta tanah air. Jika hasil validasi tiga pakar ahli kebahasaan dan Pendidikan Agama Islam, uji coba terbatas, dan uji coba luas digabungkan dan dirata-rata, maka hasilnya sebagaimana tabel 3.7 berikut ini:

Tabel 3.7. Data skor rata-rata validasi tiga pakar ahli, mahasiswa objek uji coba terbatas, dan mahasiswa objek uji coba lebih luas

\begin{tabular}{|c|c|c|c|c|c|c|}
\hline \multirow[b]{2}{*}{$\begin{array}{l}\mathbf{N} \\
\mathbf{o}\end{array}$} & \multirow[b]{2}{*}{$\begin{array}{c}\text { Aspek } \\
\text { Penilaian }\end{array}$} & \multicolumn{3}{|c|}{ Rerata Hasil Validasi } & \multirow[b]{2}{*}{$\begin{array}{c}\text { Sk } \\
\text { or } \\
\text { re- } \\
\text { rat } \\
\text { a }\end{array}$} & \multirow[b]{2}{*}{$\begin{array}{c}\text { Per- } \\
\text { sen } \\
\text { tase }\end{array}$} \\
\hline & & $\begin{array}{l}\text { Pa- } \\
\text { kar } \\
\text { Ahli }\end{array}$ & $\begin{array}{c}\text { Uji } \\
\text { Co- } \\
\text { ba } \\
\text { terba } \\
\text {-tas }\end{array}$ & $\begin{array}{c}\text { Uji } \\
\text { Co- } \\
\text { ba } \\
\text { lebih } \\
\text { luas }\end{array}$ & & \\
\hline 1 & $\begin{array}{l}\text { Kelayaka } \\
\text { n Bahasa }\end{array}$ & 4,5 & 4 & 4,3 & $\begin{array}{c}4,2 \\
6\end{array}$ & $85 \%$ \\
\hline 2 & $\begin{array}{l}\text { Kelayaka } \\
\mathrm{n} \\
\text { Konstruk } \\
\text { Penyajian }\end{array}$ & 4,5 & 4,1 & 4,2 & $\begin{array}{c}4,2 \\
6\end{array}$ & $85 \%$ \\
\hline 3 & $\begin{array}{l}\text { Kelayaka } \\
\mathrm{n} \\
\text { Konten/I }\end{array}$ & 4,8 & 4,2 & 4,3 & $\begin{array}{c}4,4 \\
3\end{array}$ & $89 \%$ \\
\hline
\end{tabular}




\begin{tabular}{|l|c|c|c|c|c|}
\hline \multicolumn{1}{|c|}{ si } & & & & & \\
\hline Jumlah & 13,8 & 12,3 & 12,8 & $\begin{array}{c}12, \\
95\end{array}$ & $86 \%$ \\
\hline Skor rerata & $\mathbf{4 , 6}$ & $\mathbf{4 , 1}$ & $\mathbf{4 , 2 6}$ & $\begin{array}{c}\mathbf{4 , 3} \\
\mathbf{2}\end{array}$ & $\mathbf{8 6} \%$ \\
\hline Katagori & $\begin{array}{c}\text { Sang } \\
\text { at } \\
\text { Baik }\end{array}$ & Baik & $\begin{array}{c}\text { Sang } \\
\text { at } \\
\text { Baik }\end{array}$ & $\begin{array}{c}\text { Sa } \\
\text { ng } \\
\text { at } \\
\text { Ba } \\
\text { ik }\end{array}$ & $\begin{array}{c}\text { San } \\
\text { gat } \\
\text { Bai } \\
\mathbf{k}\end{array}$ \\
\hline
\end{tabular}

Berdasar pada tabel 3.7. skor ratarata tertinggi diperoleh dari aspek konten atau isi buku ajar PAI yaitu 4,43 atau persentase $89 \%$ berkatagori "Sangat Baik". Skor terendah didapat dari aspek kelayakan bahasa dan kelayakan konstruk penyajian yang sama memiliki skor rerata 4,26 atau persentase 85\% berkatagori "Sangat Baik". Dilihat dari subyek penilai, penilaian pakar ahli memperoleh skor rata-rata tertinggi, yaitu 4,6 dengan katagori "Sangat Baik". Skor rata-rata terendah diperoleh dari validasi mahasiswa uji coba terbatas dengan skor rata-rata 4,1 dengan katagori "Baik". Jika dirata-ratakan semua penilaian dari tiga validator di atas, maka produk PAI baru ini memperoleh skor rata-rata 4,32 atau $86 \%$ dengan kata gori "Sangat Baik". Jika katagori "Cukup Baik" merupakan nilai minimal untuk mengukur kelayakan sebuah buku ajar PAI, maka buku ini telah melebihi batasan "Cukup Baik" dari semua penilaian validator.

Jika dilihat dari penilaian menurut tiga aspek kelayakan, maka masingmasing aspek berkatagori "Sangat Baik". Kelayakan bahasa memperoleh skor ratarata 4,26 atau persentase $85 \%$ dengan katagori "Sangat Baik". Kelayakan konstruk penyajian memperoleh skor rata-rata sama 4,26 atau persentase $85 \%$ dengan katagori "Sangat Baik". Kelayakan konten memperoleh skor rata-rata tertinggi yaitu 4,43 atau persentase 89\% dengan katagori "Sangat Baik". Atau jelasnya bisa dilihat di Tabel 3.8. berikut ini:

Tabel 3.8. Hasil Analisis Kelayakan buku PAI berdasarkan pada tiga aspek kelayakan dari tiga dosen pakar ahli, mahasiswa uji coba terbatas, dan mahasiswa uji coba lebih luas

\begin{tabular}{|c|l|c|c|c|}
\hline $\begin{array}{r}\mathbf{N} \\
\mathbf{o}\end{array}$ & $\begin{array}{c}\text { Aspek } \\
\text { Penilaian }\end{array}$ & $\begin{array}{c}\text { Skor } \\
\text { rerata }\end{array}$ & $\begin{array}{c}\text { Per- } \\
\text { sentase }\end{array}$ & $\begin{array}{c}\text { Katagor } \\
\mathbf{i}\end{array}$ \\
\hline 1 & $\begin{array}{l}\text { Kelayakan } \\
\text { Bahasa }\end{array}$ & 4,26 & $85 \%$ & $\begin{array}{c}\text { Sangat } \\
\text { Baik }\end{array}$ \\
\hline 2 & $\begin{array}{l}\text { Kelayakan } \\
\text { Konstruk } \\
\text { Penyajian }\end{array}$ & 4,26 & $85 \%$ & $\begin{array}{c}\text { Sangat } \\
\text { Baik }\end{array}$ \\
\hline 3 & $\begin{array}{l}\text { Kelayakan } \\
\text { Konten/Isi }\end{array}$ & 4,43 & $89 \%$ & $\begin{array}{c}\text { Sangat } \\
\text { Baik }\end{array}$ \\
\hline Jumlah & 12,95 & $86 \%$ & $\begin{array}{c}\text { Sangat } \\
\text { Baik }\end{array}$ \\
\hline \multicolumn{2}{|l|}{ Skor rerata } & 4,32 & $\mathbf{8 6} \%$ & $\begin{array}{c}\text { Sangat } \\
\text { Baik }\end{array}$ \\
\hline
\end{tabular}

Dari Tabel 3.8. di atas dapat dianalisa dan dinilai bahwa skor rata-rata dari semua aspek penilaian memperoleh skor rata-rata 4,32 dengan persentase $86 \%$ yang termasuk dalam katagori "Sangat Baik". Karena itu buku PAI berbasis pendidikan karakter dan jiwa nasionalis ini layak dan valid digunakan bagi calon pendidik di perguruan tinggi keguruan dan ilmu pendidikan.

\section{KESIMPULAN}

Berdasarkan tahapan penelitian dan pengembangan dapat disimpulkan bahwa buku ajar Pendidikan Agama Islam berbasis pendidikan karakter dan jiwa nasionalis ini dapat memenuhi kebutuhan mahasiswa calon pendidik. Terutama dalam upaya deradikalisasi pemahaman agama, penerapan akhlak mulia dan adab belajar mengajar, pendidikan keluarga, dan cinta tanah air Indonesia. Terbukti nilai rata-rata respon 
mahasiswa terhadap efektifitas, kualitas, standarisasi, dan nilai tambah produk buku PAI baru lebih tinggi daripada buku lama. Skor rata-rata buku baru 4,25 atau persentase $85 \%$ lebih tinggi daripada buku lama yang memiliki skor rata-rata 2,5 atau persentase $50 \%$.

Buku PAI ini juga sangat valid dan layak untuk digunakan dalam pembelajaran PAI di perguruan tinggi keguruan dan ilmu pendidikan. Hasil validasi gabungan menurut pakar ahli kebahasaan dan Pendidikan Agama Islam, serta mahasiswa menunjukkan buku ini layak digunakan dengan predikat "Sangat Baik", dengan skor rata-rata 4,32 atau $86 \%$. Dengan perincian kelayakan bahasa $4,26 \%$ atau $85 \%$, kelayakan konstruk penyajian 4,26 atau $85 \%$, dan kelayakan konten 4,43 atau $89 \%$.

Hasil penelitian dan pengembangan ini dapat dijadikan bahan acuan untuk penelitian sejenis selanjutnya. Produk buku ajar PAI ini dapat dikembangkan lagi mengingat materi tentang keberagamaan dan ijtihad para ulama di berbagai bidang juga berkembang. Buku ajar PAI ini juga dapat dimanfaatkan untuk pembelajaran PAI di perguruan tinggi keguruan dan ilmu pendidikan lain, dibaca dan dikaji di perpustakaan perguruan tinggi, dibaca dan diimplementasikan oleh mahasiswa, guru, dosen, dan orang tua di rumah.

\section{UCAPAN TERIMA KASIH}

Ucapan terima kasih yang mendalam dan sebanyak-banyaknya disampaikan kepada Dirjen Riset dan Pengabdian Masyarakat (DRPM) Kementrian Riset dan Teknologi Pendidikan Tinggi yang memberikan dana hibah Penelitian Dosen Pemula (PDP) anggaran 2018. Tidak lupa juga disampaikan kepada Ketua STKIP Al Hikmah, para expert reviewer Buku Ajar PAI baru, rekan-rekan sesama dosen, keluarga yang selalu mendukung dan memberi motivasi, serta seluruh mahasiswa di semua program studi STKIP Al Hikmah Surabaya.

\section{REFERENSI}

Badan Standar Nasional Pendidikan. (2007). Petunjuk Penggunaan Instrumen Penilaian. Jakarta: BSNP.

Borg, Walter R \& Gall, Meredith D. (2003). Educational Research. New York: Longman.

Budimansayah, D \& Komalasari, K. (Eds). (2011). Pendidikan Karakter: Nilai Inti Bagi Upaya Pembinaan Kepribadian Bangsa (Penghargaaan dan Penghormatan 70 Tabun Prof. Dr. H. Endang Somatri, M.Ed. Bandung: Widya Aksara Press.

Dirjen Belmawa Kementerian Riset, Teknologi, dan Pendidikan Tinggi. (2016). Buku Bahan Ajar Mata Kuliah Wajib PAI. Jakarta: Dirjen Belmawa Ristekdikti.

Plomp, T \& Nieveen, N. (2007). An Introduction to Educational Design Research. Enschede: SLO.

Saidi, Anas. (2017) "Mahasiswa Islam dan Masa Depan Demokrasi di Indonesia" KOMPAS, 19 Februari 2017.

Sugiono. (2016). Metode Penelitian Kuatitatif, Kualitatif, dan $\mathrm{R}$ \& $D$. Bandung: Penerbit Alfabeta. 
Sukardjo, dan Permana Sari, Lis. (2009). Metodologi Penelitian Pendidikan Kimia. Yogyakarta: FMIPA UNY.

Sukmadinata, Nana Syaodih, DKK. (2005). Metode Penelitian Pendidikan. Bandung: Rosdakarya.

Suwendi. (2017). "Persoalan Dosen PAI Pada Perguruan Tinggi Umum" Suara Nabdhotul Ulama (Online) diupload tanggal 18 Maret 2017 dan diakses tanggal 9 Mei 2017 di http:// www.nu.or.id/post/read/ 76224/persoalan-dosen-pai-padaperguruan-tinggi -umum

Tim Pusat Bahasa Kemdiknas. (2016). Kamus Besar Bahasa Indonesia. [Online] Diakses 21 Maret 2017 di http://kbbi. web.id/rehabilitasi

\section{Surat Keputusan dan Undang-} Undang:

Direktur Jendral Dikti Depdiknas. (2006). Surat Keputusan Dirjen Dikti Nomor 43/DIKTI/Kep/2006 tentang Rambu-Rambu Pelaksanaan Kelompok Matakuliah Pengembangan Kepribadian di Perguruan Tinggi.

Undang-Undang Nomor 22 tahun 1961 tentang Perguruan Tinggi

Ketetapan MPRS No XXVII/MPRS/1966 tentang Penetapan Pendidikan Agama.

Undang-undang Nomor 20 tahun 2003 tentang Sistem Pendidikan Nasional Republik Indonesia pasal 339

Undang-Undang Nomor 12 Tahun 2012 tentang Pendidikan Tinggi Pasal 35 Ayat 3

Peraturan Menteri Riset Teknologi dan Pendidikan Tinggi No 44 tahun
2015 tentang Standar Nasional Pendidikan Tinggi (SN Dikti). 